\title{
DIGITAL INTELLIGENCE: CONSUMPTIVE BEHAVIOR REDUCTION EFFORTS GLOBAL SOCIETY AGAINST HOAX INFORMATION
}

\author{
Iis Eka Wulandari \\ IAINU Kebumen \\ iisekawulandari@gmail.com
}

\begin{abstract}
The development of information technology contributes to creating media diversity. This rapid development has triggered a shift in the availability of access from limited access to abundant media. The birth of cyber media is one sign of this diversity. However, not everything that develops has a positive impact, but many audiences complain about the reality that has entered the era of a world crowded with media. The existence of this phenomenon gives rise to freedom in the creation and dissemination of information which leads to the delivery of irresponsible messages. So that the phenomenon of the spread of fake news or hoaxes is increasing significantly in Indonesia and even in the world. Unfortunately, most netizens who take part in this new media era do not pay attention to cyber media law and ethics. In addition, they also lack knowledge about what, why and how media literacy is applied. From the emergence of this problem, it is important for netizens and audiences to know the importance of digital intelligence, as an effort to reduce the consumptive behavior of the global community in consuming information from hoax crimes..
\end{abstract}

\section{Keywords: Cyber Media, Hoax, Digital Intelligence}

\section{INTRODUCTION}

The development of technology in the era of globalization is directly proportional to the rapid development of mass media in Indonesia. Information technology essentially contributes to the emergence of media diversity. The growth of mass media which has grown from print media to television and radio electronic media, now media growth has reached cyber media or cyber media. This growth always offers renewal in accordance with the desires of the digital society (digital society). Digital society is the reality of the lives of Indonesian people who have entered the twenty-first century, where their lives are always in contact with advances in digital technology, including in the means of communication. Treats that intersect with practicality, speed of access and generate profits, are the main attraction for the global community.

The entry of cyber media in the era of globalization provides convenience in the means of communication, not only for the audience but also for its creators, not 
only for writers but also for readers, as well as providing convenience not only for speakers but also for those who listen. Freedom in managing websites, news portals, blogs and social media is an offer in it. Of the offers that have been given by cyber media, social media is the most likely in society. This is because the way to access and manage social media is very easy for netizens in all circles. Starting from children, teenagers, adults to the elderly, most of them can operate social media devices.

The new media environment gave birth to a shift from the availability of media which was initially limited due to scarce access to abundant media. The practical value in disseminating information or news is not only carried out by someone who works as a journalist, but can be done by ordinary people, students, academics, professors, officials or others. They easily provide any information via their social media or other cyber technology offerings. The emergence of freedom in this means of communication provides a bridge for every individual to become citizen journalism.

Unfortunately, the presence of freedom in the delivery of information messages does not only have a positive impact, but also has an unfavorable and even detrimental impact on a number of groups. The bad effects that arise from this freedom are not only for society in general, but also for certain groups or even individuals. As time goes by, it is not surprising if the news circulating in the mass media is nothing but news whose truth is still in doubt. The rise of news among netizens is often referred to as a hoax or news that contains false information.

Fake news or familiarly called hoaxes has gradually become a skewed phenomenon in Indonesia in particular, and in various countries in general. Freedom of media provides an opening for communication actors. Not a few of the emergence of this hoax phenomenon caused provocations that led to disputes between individuals, political groups, social groups and even religious people. Hoaxes that are motivated by economic, religious or political interests are a separate agenda setting to hunt clicks in order to reap multiple benefits in such a short time. From the emergence of news problems related to false information, understanding digital intelligence has an urgent position to be owned by every individual or group as a new media user in this era. Digital intelligence is needed not only to create a 
literacy culture, but also as a means for the global community to be able to enter the world of digital media competition. From some of the explanations above, therefore, the author will provide an explanation of the urgency of digital intelligence in dealing with the hoax phenomenon and how the global community should behave in facing the cyber world.

\section{CYBER MEDIA}

Media in the network is a feature of the emergence of new media or cyber media. Cyber media or what is familiarly called cyber media, provides media opportunities in internet mediation for the wider community. The development of the internet network provides choices for the public, not only in finding and consuming information, but also in contributing to the production of information. The development of cyber media does not only refer to technology, but also refers broadly to social, political, economic, cultural, religious, and other aspects ${ }^{1}$.

The shift in media made Holmes divide the media from a historical perspective into the first media age (first media age) with a broadcast pattern and the second media age (second media age) with an interactivity pattern, as described in the following table: ${ }^{2}$

Table 1. Comparison of the First Media Era and Second Media Era

\begin{tabular}{|l|l|}
\hline \multicolumn{1}{|c|}{ The First Media Era (Broadcast) } & Second Media Era (Interactivity) \\
\hline $\begin{array}{l}\text { Centralized (from one source to many } \\
\text { audiences) }\end{array}$ & $\begin{array}{l}\text { Scattered (from many sources to } \\
\text { many audiences) }\end{array}$ \\
\hline One-way communication & $\begin{array}{l}\text { Two-way communication, feedback } \\
\text { occurs }\end{array}$ \\
\hline $\begin{array}{l}\text { Open source or media opportunities to } \\
\text { master }\end{array}$ & $\begin{array}{l}\text { Closed media control and free } \\
\text { control over sources }\end{array}$ \\
\hline $\begin{array}{l}\text { Media is an instrument that perpetuates } \\
\text { strata and inequalities of social class }\end{array}$ & Media facilitates every audience \\
\hline $\begin{array}{l}\text { The audience is fragmented and perceived as } \\
\text { mass }\end{array}$ & $\begin{array}{l}\text { The audience can be seen according } \\
\text { to the character and without leaving } \\
\text { the diversity of their respective } \\
\text { identities }\end{array}$ \\
\hline
\end{tabular}

${ }^{1}$ Asna Istya Marwantika, "TREN KAJIAN DAKWAH DIGITAL DI INDONESIA : SYSTEMATIC LITERATURE REVIEW," Proceeding of Conference on Strengthening Islamic Studies in The Digital Era 1, no. 1 (2021): 249-65, https://prosiding.iainponorogo.ac.id/index.php/ficosis/article/view/37.

${ }^{2}$ Rulli Nasrullah, Cyber Media (Yogyakarta: IDEA Press, 2013), p. 17. 


\begin{tabular}{|l|l|}
\hline $\begin{array}{l}\text { Media is considered to be able or as a tool to } \\
\text { influence consciousness }\end{array}$ & $\begin{array}{l}\text { Media involves the experience of } \\
\text { audiences both in space and time }\end{array}$ \\
\hline
\end{tabular}

Source: Cyber Media Rulli Nasrullah

Cyber media is slowly forming a new media environment that focuses on problems not only about messages, but information technology itself which is one form of the social environment. According to the table above, the emergence of interactive media allows the audience to be in the position of consumers as well as producers of information. Meanwhile, according to Van Dijk, interaction in cyber media occurs when four dimensions appear, including: interactive media, synchronization, the occurrence of flexibility of control, and the interaction process is in line with understanding. ${ }^{3}$

The birth of a new media environment or known as cyber-space, is basically an innovation of media technology, for the convenience of means of communication for the global community. Humans as social beings will never be separated from the communication process. The presence of cyber media gives a new face to the process, namely the shift from real interactions to virtual interactions. Digital technology covers how humans interact using modern technology. This type of communication is known as the digital society.

\section{DIGITAL SOCIETY}

In the era of traditional media, audiences are placed as objects defined by the media as "audience-as-object". In this statement, it means that the public as audiences are placed in a passive position, have no freedom to produce information and have a tendency to just accept media exposure. The development of information technology marked by the entry of the cyber world era gave birth to a shift in the position of the audience. The audience in the cyber world is no longer in a passive position, but is active by having the authority to use the medium. Digital society has the freedom to transform itself in distributing information (news). In this case, the

\footnotetext{
${ }^{3}$ Rulli Nasrullah, Cyber Media, p. 21.
} 
rapid pace of information technology has indeed provided a transformation of communication patterns from traditional media to new media. ${ }^{4}$

Now the communication that occurs does not use the pattern of one source to various sources (broadcast), where the audience tends to be centered, passive and isolated, but communication now is not centralized, active, and dynamic. ${ }^{5}$ Digital-based communication information technology requires people to be able to merge with digital developments. Positively, people who were originally only objects have now shifted to become internet citizens (Netizens), which are facilitated by the media. Netizens can even occupy positions as citizen journalism or citizen journalism. This means that as citizen journalism, the public can actively participate in the search, collection and reporting of news or information. So that with the entry of the era of digital society, people can simultaneously produce, distribute and consume information (news) created.

Although many positive aspects are found in digital media, the development of media digitization does not only provide opportunities for netizens to carry out positive effective communication. On the other hand, the actions of the digital community are also motivated by massive negative goals, which then lead to criminal acts in cyberspace. One of the results of the media tightness is the rise of the hoax phenomenon which is increasingly becoming a state of concern.

\section{DYNAMICS OF HOAX PROBLEMS}

Hoax is not a new word that appears in the millennial era, but its appearance has been around since 1808, comes from English which means fake news or fake news. Many people think the word hoax comes from the word 'hocus' - taken from 'hocus pocus' a word that is often used by magicians (a kind of sim salabim). According to Lynda Walsh in a book entitled Sins Against Science, the term hoax or false news is a term in English that has entered since the industrial era, which is estimated to have first appeared in 1808. In Indonesia itself, the government has responded firmly to the spread of false information, even the president. Republic of Indonesia. The

\footnotetext{
${ }^{4}$ Marwantika, Asna. 2019. "Potret Dan Segmentasi Mad'u Dalam Perkembangan Media Di Indonesia". Al-Adabiya: Jurnal Kebudayaan Dan Keagamaan 14 (01), 1-14. https://doi.org/10.37680/adabiya.v14i01.100.

${ }^{5}$ Rulli Nasrullah, Cyber Media, 74.
} 
President of the Republic of Indonesia in a Limited Cabinet Meeting Towards the end of the year, ordered law enforcement officials to take firm action against hoax spreaders.

The term hoax is an absorption from English which has recently been widely used by netizens, print mass media and electronic mass media, regarding the widespread circulation of fake news. According to the UI lib.periodic team, regarding indicators to watch out for regarding this hoax phenomenon, among others: 6

a. Title

Making news headlines or news titles that are part of the news content, is usually made as attractive as possible to attract the interest of readers. Hoax perpetrators usually make provocative titles, even though they are not in accordance with the content of the news. Therefore, make sure to read the contents of the news before taking the share action.

b. News writer

A form of responsibility from a writer for the news that is written is to include the name or initials at the beginning or at the end of the article. So to make sure the information is a hoax or not, it can be seen whether the author is competent in the field he is writing about.

c. News site address

In the era of digital society, creating a news portal on an online site is very easy to do. The existence of this freedom of information dissemination is often used by hoax actors to create sites with names similar to leading sites. So check first before we trust the site and do click and share actions. DPI (Indonesian Press Council) has verified the available online sites, so that it can be used as a reference to see if the news source has met the journalistic rules according to the applicable press regulations. Some of them are Media Indonesia, kompas.com, viva.co.id, detik.com and so on.

d. Distinguish facts from opinions

Whether news is made on the basis of facts or just opinions is something that is important to note. The more factual content in the news, the more reliable the news.

${ }^{6}$ UI lib.berkala, “Stop Menyebarkan Hoax,” p. 26. 


\section{e. Check primary sources of scientific news}

When writing articles, papers or final assignments, they are often reminded that blogs or wikipedia are not scientific sources that can be used as references. The same goes for news writing. The truth of the information content can be checked through the primary source of the writing, for example by looking at the journal or article written by the resource person. Because good writing must include the source of the article.

The practical culture of social media that leads to the freedom to deliver messages that are not responsible gives rise to fake news or hoaxes. This hoax phenomenon is a rumor whose truth is still in doubt and cannot be used as the basis for anything. Lately, hoaxes have become a concern among the general netizens. The existence of hoaxes was followed by a significant increase in the spread. In this era of media congestion, hoax forms and channels such as writing, images or videos are easily channeled through social media, chat applications, websites, television, print media, email, radio and several social media applications..

During the pre-internet era, the media that had the authority to disseminate information were media that had received government permits in the form of SIUPP (Press Publishing Business License). ${ }^{7}$ Thus, information facilities are still relatively limited, the dissemination of information is fairly clear, regarding the regulations for the distribution and creation of information. Then if there is a violation made by the media, the sanction is the closure of the media concerned by the government. In this era, it can be said that the Indonesian press is a free and responsible press so that the prevention of hoax behavior can be easily anticipated.

With the birth of the internet age, everything about clear and responsible press regulations gradually faded away and banal freedom ensued. The existence of the phenomenon of the birth of hoaxes is marked by the freedom to create information through the internet. The proliferation of the hoax phenomenon in society is triggered by the emergence of new technology, by allowing anyone to freely create information in accordance with the interests of the creator. The number of netizens who are engaged in the creation of cyber information, have their respective backgrounds. Unfortunately, not all backgrounds are packed with

\footnotetext{
7 UI lib.berkala, "Stop Menyebarkan Hoax," p. 3.
} 
positive intentions, but most of them are motivated by irresponsible acts in various fields. For example, the creation of false information is motivated by propaganda in religious talks, as a form of black campaign strategy in politics, creating a bad image of officials or vice versa in the social field, bringing down business opponents and so on.

In this respect, the positive impact of this phenomenon is only for some groups who are planning the criminal act, the rest for those who are attacked by hoaxes do not get a pleasure but a loss. The more sophisticated the technology of cyber media, especially social media, the types of hoaxes also increase and are increasingly dangerous. To make it easier to identify the hoax phenomenon, there are six types of hoaxes that the global community needs to be aware of. ${ }^{8}$ First, Hoax Virus. This hoax contains a warning message of a dangerous virus on a personal computer, laptop or smartphone that is not actually infected. This false information is usually developed by hackers via email, chat applications or suddenly appears on certain sites. The victim will be asked to install a certain application or delete a file on the device, which actually gives an opportunity to hack the system on the victim's device.

Second, hoaxes send chain messages. Chain messages lead to the spread or known as click and share. Of course, netizens often get messages via whatsapp, fuel or other social media, then instructions appear to spread them. If you don't share it, you will experience bad things or something else. Although it seems trivial, but this can cause public panic. The act of fowarding can also give a negative image, especially among professionals. Third, Hoax urban legend. False information about a place, object or activity is considered something scary, bad and must be avoided, is an act of provocation of hoax behavior. This type of hoax usually directs netizens to avoid the intended hoax object. So that the object is shunned or even its economic value goes down. This kind of hoax is similar to the action of a black campaign.

Fourth, Hoax get free gifts. The circulation of broadcast messages about congratulations on getting the lottery is a hoax crime mode that is similar to online fraud. Sometimes the victim rarely or does not lose money, but sometimes they are

8 https://www.merdeka.com/teknologi/6-jenis-hoax-internet-yang-wajib-diwaspadainetizen.html, Accsessed at 25 March 2021 
deceived by filling out internet surveys that are used for advertising. The danger is if the victim enters a company email to take part in the fake survey. Next, Hoax is a sad story. This hoax can be said to be a trap through someone's suffering that is uploaded in the mass media, even though photos of the sufferer are only taken through certain sites. Then the end - the end is to ask for donations in the form of money. The victim who is consumed will send some money to the account number listed. Last Hoax defamation. Even though it is only a name, but if badness is brought, it can easily spread on cyber media and destroy the reputation of a person or a certain group. As experienced by seventy-four-year-old Australian grandfather Kenneth Rothe.

\section{INTELLIGENT AND ETHICAL NETIZEN}

Responding intelligently to digital phenomena will have a positive impact on users. The public can take a positive effect on why this phenomenon can occur, for example deepening media literacy. Awareness of the importance of media literacy will minimize the gaps that occur in digital society. This is because the aspect of changing the perspective of the mass media will be realized little by little. In addition, the development of media literacy will protect the public from the negative impacts of mass media, such as hoaxes. According to the Canadian Ministry of Education, media literacy is: ${ }^{9}$

"With regard to helping students to develop a critical and well-informed understanding of the nature of mass media, the techniques used by the mass media and the impact of using these techniques. More specifically, media literacy is education that aims to increase students' understanding of the media, how media work, how media produce meaning, how media are organized and how to construct reality. Media literacy also aims to give students the ability to make media products."

Media literacy for digital society in the 21st century is defined as more than just reading and writing, but entering components that enrich knowledge and

9 Yosal Iriantara, Literasi Media; Apa, Mengapa, Bagaimana (Bandung: Simbiosa Rekatama Media, 2009), p. 91. 
thinking skills that integrate social, professional and technological developments. There are four components related to media literacy. First, technological literacy. Ability to be in line with technological developments in the use of media. For example, the birth of the internet, so that users can access and communicate information effectively.

Second Information literacy. Ability to manage information, including collecting, organizing, filtering and evaluating information. So from this ability will form a solid opinion. Next, media creativity. The ability to develop creativity and the ability to disseminate individual content to the public. Finally, social responsibility and competence. Competence to take into account the social consequences of online publications.

The emergence of hoaxes illustrates the bias between subjects and objects that spread information. Between the subject or the creator with a background of certain goals and intentions then the message is received by the object or recipient of information who is always the recipient and then disseminates it in a relatively short duration. Actions like this then identify gaps in the evaluation process for receiving information. So that hoaxes are rampant.

In line with the development of cyber media, as a digital society, understanding of the media must also increase. The urgency of various free news should not be swallowed raw and then immediately carry out the act of spreading it spontaneously. As a smart netizen, media literacy is very important in addressing this problem.

Basically, media literacy is a learning effort for media audiences so that they become audiences who are empowered to live in a world called media-saturated. Literacy in media literacy makes us have the ability not only to understand the news content, but also to be able to analyze and deconstruct the imagery of any information that is spread through cyber media. The development of media literacy was formed from the inclusion of media education with the main objective of protecting the younger generation. The next development is not only for the younger generation, but for the next generation so that they can live in a mediacrowded era. Conceptually, viewing the development of media literacy as a learning 
QAULAN, Vol. 2, No.2, Desember 2021

Iis Eka Wulandari, Digital Intelligence....

effort for mass media audiences, will show the connection between education science and mass communication.

According to Baran and Davis, there are several things that underlie the thought of the importance of media literacy. Some of the points include:10

a. a. Audiences are active, but they are not necessarily aware of what they are doing with the media.

b. b. Audience needs, opportunities and choices are driven unnaturally by access to media and media content

c. Media content can implicitly or explicitly provide guidelines for action.

d. People must realistically measure how their interactions with media texts can determine the goals that these interactions support them in their environment.

e. e. People have different levels of cognitive processing, and this can radically affect how they use media and what they can get out of it.

Besides being smart in responding to cyber culture. As a digital media user, understanding and applying ethics also needs to be considered. Internet ethics (Netiquette) comes from the word "Net" to describe the network (network) or it could be the internet and "etiquette" which means ethics or values applied in communication in the cyber world.. ${ }^{11}$ In essence, netiquette is internet ethics as well as social behavior that applies in online media. Although communication takes place in the virtual world, standard rules of communication or relationships between individuals are also needed as in the real world. Ethics in the internet is considered important for several reasons, including: 12

a. The use of cyber media is not equal and comes from the same environment

b. Communication that occurs in cyber media tends to rely on text alone

c. c. In cyber media, content is not directly directed to the desired user, but can happen indirectly

\footnotetext{
${ }^{10}$ Apradi Tamburaka, Literasi Media: Cerdas Bermedia Khalayak Media Massa (Jakarta: Rajawali Pers, 2013), p. 4.

${ }^{11}$ Rulli Nasrullah, Cyber Media, p. 144.

${ }^{12}$ Rulli Nasrullah, Rulli Nasrullah, Cyber Media, p. 145-47.
} 
d. d. Cyber media is not merely considered as a media that is different and separated from the real world

e. e. Internet etiquette is needed so that users understand their rights and obligations in the virtual world

Kejahatan di dunia siber termasuk perilaku hoax, sama halnya dengan kejahatan kriminal dan illegal yang pada tindakannya merugikan banyak pihak. Dalam menyikapi fenomena ini pemerintah memberikan undang undang tegas menyikapinya untuk menjerat para pelaku tindak kejahatan yang terkait dengan komputer dan jaringan internet. Beberapa peraturan itu terkait hukum dan etika berinternet adalah sebagai berikut: ${ }^{13}$

a. Article 28 paragraph 1 of Law No. 11 of 2008 concerning Information and Electronic Transactions. Anyone who intentionally and or without rights spreads false and misleading news, the threat can be punished by a maximum of six years and a maximum fine of Rp. 1 billion.

b. Article 28 paragraph 2 of Law No.11 of 2008 concerning Information and Electronic Transactions. "Every person intentionally and without rights distributes information that is intended to cause hatred or hostility to certain individuals and/or community groups based on ethnicity, religion, race, and intergroup (SARA)".

c. Law Number 1 of 1946 concerning Criminal Law Regulations. Article 14 paragraph (1) Whoever, by broadcasting false news or notification, intentionally causes trouble among the people, shall be punished with a maximum imprisonment of ten years. Article 14 paragraph (2) Whoever broadcasts a news or issues a notification that can cause trouble among the people, while he should be able to think that the news or notification is a lie, is sentenced to a maximum imprisonment of three years..

d. Law Number 1 of 1946 concerning Criminal Law Regulations. Article 15 paragraph (1) Whoever, by broadcasting false news or notification, intentionally causes trouble among the people, shall be punished with a

${ }^{13}$ https://www.viva.co.id/digital/digilife/850193-deretan-pasal-dan-ancaman-pidana-bagipenyebar-hoax, . accessed at 25 March 2021. 
maximum imprisonment of ten years. Article 15 paragraph (2) Whoever broadcasts a news or issues a notification that can cause trouble among the people, while he should be able to think that the news or notification is a lie, is sentenced to a maximum imprisonment of three years.

\section{DIGITAL INTELLIGENCE}

Digital intelligence (Digital Intelligence) is a set of technical, cognitive, metacognitive and socio-emotional competencies based on universal moral values that enable individuals to face the challenges of digital life and adapt to its demands.. ${ }^{14}$ In a massive world competition, people are required to understand technological developments, at least how to use them and anticipate digital crimes that are rampant. Understanding digital intelligence is used not only to understand existing digital media, but to solve problems, making it easier for people to jump into global competition..

The development of technology and information, which has entered the industrial revolution 4.0, indicates that significant changes in the future will continue. The digital era has indirectly entered all lines of life. Some of them are in the fields of education, transportation, data retrieval, the availability of digital libraries. Even to circumnavigate the world, simply surfing via virtual is able to fulfill the search. Some of the descriptions above confirm that the global community is definitely in contact with the digital world in their daily life. Therefore, as a digital user, basic skills in use must be possessed by every user. A user must understand the aspects in digital intelligence. How to effectively use the internet, how to take advantage of various applications. These two basic questions always lead users to be more efficient.

The form of digital intelligence can be taken from the phenomenon of the Covid-19 pandemic. The position of the community in dealing with this epidemic should not be included in the position of the object as a victim, but in the position of

14 DQ Institute. Leading Digital Education, Culture and Innovation, "DQ Global Standards Report 2019, Common Framework for Digital Literacy, Skills and Readiness," $D Q$ Institute. Leading Digital Education, Culture and Innovation, 2019, p. 12. 
the subject who can always take advantage of the pandemic era. In the education sector, for example, the lecture method which is usually done face-to-face in class, can be replaced by face-to-face in online virtual classes. The various media applications available must be used wisely and as well as possible.

Digital intelligence essentially brings changes to society about how to deal with the current digital era. Understanding of digital intelligence provides an understanding of technology for the community to apply it in solving social problems. According to the DQ Institute, there are 3 levels of digital intelligence. First, Digital Citizenship, namely the ability to use digital technology and media in a safe, responsible and ethical manner. Next is Digital Creativity, which is the ability to be part of the digital ecosystem and create new knowledge, technology and content that turns ideas into reality. The last level is Digital Competitiveness, namely the ability to face global challenges, be innovative, create new opportunities for the digital economy by encouraging entrepreneurship, employment, growth and impact.

The understanding of the global community about digital intelligence does not only provide anticipation for criminal hoaxes. More than that, people are in the position of members of the digital economy who are intelligently involved in digital competition globally, such as creating jobs, as entrepreneurs, or becoming social influencers.

\section{CONCLUSION}

Fake news or hoaxes that have recently been widely publicized have become a problem for countries and even the world. The era of media congestion has made a shift from a passive audience to an active audience towards the creation of media content. This is influenced by the development of information technology that has entered the cyber world. Freedom is a tantalizing offer for interested actors from diverse backgrounds. Responding to this phenomenon as a preventive measure against the proliferation of the hoax phenomenon, there are several important things to note.

First, be a smart and ethical netizen. One way is to study media literacy. Understanding of media literacy will make the audience know why a text is 
constructed. Thus, internet residents or netizens will be more careful in receiving information, as well as in disseminating information before any clarification action is taken. Next, know the law and ethics of cyber media. Smart netizens are those who don't just post and share by putting aside internet ethics and are blind to applicable laws. Indonesia, in its legal regulations, has also explicitly provided laws related to the use of cyber media. So that being literate with internet ethics will minimize hoax perpetrators, because little by little netizens understand the rights and responsibilities of using the internet.

Second, understand the level of digital intelligence. First, Digital Citizenship, namely the ability to use digital technology and media in a safe, responsible and ethical manner. Next is Digital Creativity, which is the ability to be part of the digital ecosystem and create new knowledge, technology and content that turns ideas into reality. The last level is Digital Competitiveness, namely the ability to face global challenges, be innovative, create new opportunities for the digital economy by encouraging entrepreneurship, employment, growth and impact. By understanding digital intelligence, the global community as users is not only protected from criminal hoaxes, but also can compete in the use of technology and digital media in the growth of the creative economy..

\section{REFERENCES}

Apradi Tamburaka. Literasi Media: Cerdas Bermedia Khalayak Media Massa. Jakarta: Rajawali Pers, 2013.

DQ Institute. Leading Digital Education, Culture and Innovation. "DQ Global Standards Report 2019, Common Framework for Digital Literacy, Skills and Readiness." DQ Institute. Leading Digital Education, Culture and Innovation, 2019.

Rulli Nasrullah. Cyber Media. Yogyakarta: IDEA Press, 2013.

UI lib.berkala. "Stop Menyebarkan Hoax." Universitas Indonesia 3, no. 1 (2017).

Yosal Iriantara. Literasi Media; Apa, Mengapa, Bagaimana. Bandung: Simbiosa Rekatama Media, 2009.

Liputan 6. "Darimana Asal Usul Hoax?" News, 2017. https://www.liputan6.com/news/read/2820443/darimana-asal-usulhoax. 
QAULAN, Vol. 2, No.2, Desember 2021

Iis Eka Wulandari, Digital Intelligence....

Viva.co.id, https://www.viva.co.id/digital/digilife/850193-deretan-pasal-danancaman-pidana-bagi-penyebar-hoax, diakses pada tanggal 31 Maret 2018.

Marwantika, Asna. 2019. “Potret Dan Segmentasi Mad'u Dalam Perkembangan Media Di Indonesia". Al-Adabiya: Jurnal Kebudayaan Dan Keagamaan 14 (01), 1-14. https://doi.org/10.37680/adabiya.v14i01.100.

Marwantika, Asna Istya "TREN KAJIAN DAKWAH DIGITAL DI INDONESIA :

SYSTEMATIC LITERATURE REVIEW," Proceeding of Conference on Strengthening Islamic Studies in The Digital Era 1, no. 1 (2021): 249-65, https://prosiding.iainponorogo.ac.id/index.php/ficosis/article/view/37.

merdeka.com, https://www.merdeka.com/teknologi/6-jenis-hoax-internet-yangwajib-diwaspadai-netizen.html, diakses pada tanggal 25 Maret 2018 